\title{
Suppression of vulpia and goose grass in dryland pastures through the choice of sown pasture species
}

\author{
K.N. TOZER ${ }^{1,2}$, G.R. EDWARDS ${ }^{1}$ and C.A. CAMERON ${ }^{2}$ \\ ${ }^{1}$ PO Box 84, Lincoln University, Lincoln 7647, \\ ${ }^{2}$ Current address: AgResearch, Ruakura Research Centre, Private Bag 3123, Hamilton 3240 \\ Katherine.tozer@agresearch.co.nz
}

\begin{abstract}
Vulpia (Vulpia myuros) and goose grass (Bromus hordeaceus) are common annual grass weeds throughout New Zealand in dryland pastures. They compete with sown species, suppressing pasture production and livestock performance. Their seeds may also damage hides and carcasses. Choice of sown pasture species can be important in limiting their spread. The abundance and fecundity of sown vulpia and goose grass was measured over 1 year in dryland Canterbury pastures sown with different grass and legume species. Survival and seedhead production of both vulpia and goose grass were lower in pastures oversown with the annual legumes subterranean and balansa clover. Annual grass weed establishment was also lower in cocksfoot than perennial ryegrass pastures. In Canterbury dryland pastures subject to summer drought, cocksfoot-based pastures oversown with subterranean and balansa clover show promise as a better alternative to ryegrassbased pastures for suppressing the ingress of these species. Repeating this study over several years in different environments would determine how widely these conclusions can be applied.
\end{abstract}

Keywords: pasture persistence, weed ingress, annual grass weeds

\section{Introduction}

Annual grass weeds can rapidly invade New Zealand dryland pastures, especially when drought stress occurs. They provide poorer quality forage than sown species and reduce pasture production and persistence. Once seedheads emerge, annual grass weeds are often avoided by grazing livestock. Their seeds can also contaminate carcasses or damage hides and pelts (Bourdôt 1996; Burton \& Dowling 2004).

One approach to the control of annual grass weeds in dryland pastures is to enhance competition from sown species and to reduce the amount of bare ground available for colonisation by annual grass weeds. Another is to reduce the fecundity of the annual grass weeds and thus their ability to regenerate (Burton \& Dowling 2004). Grass weed fecundity can also be influenced by competition from sown species (Dowling et al. 2004).
Sown perennial grasses differ in their competitive ability. Cocksfoot is more drought tolerant than ryegrass (Lolicato \& Rumball 1994) and would presumably exert greater competition in drought stressed, summerdry environments. Oversowing drought tolerant legumes, such as subterranean clover (subclover, Trifolium subterraneum) can also increase competition. For example, vulpia (Vulpia myuros) and barley grass (Hordeum murinum) survival and fecundity were reduced when subclover was oversown in dryland tall fescue (Festuca arundinacea) pastures (Tozer et al. 2007). The current study compared vulpia and goose grass (Bromus hordeaceus) establishment, survival and seed production in perennial ryegrass (Lolium perenne) and cocksfoot (Dactylis glomerata)-based pastures, and how this was affected by oversowing the annual legumes subclover and balansa clover (T. michelianum).

\section{Methods}

Site

A site was established in a 2.9 ha paddock at Ashley Dene, the dryland research farm located near Lincoln University, New Zealand. The soil is a Lismore very stony silt loam and had a $\mathrm{pH}$ (in water) $=6.4$ and an Olsen $\mathrm{P}=28$. Annual rainfall in 2005 at the site was 501 $\mathrm{mm}$ and the long-term average annual rainfall measured at Broadfields, about $14 \mathrm{~km}$ from the site, was $556 \mathrm{~mm}$ (1990 - 1999).

'Aries HD' AR1 perennial ryegrass/'Demand' white clover (T. repens) plots and 'Vision' cocksfoot/'Demand' white clover plots were established in October 2002 as a randomised complete block design with 4 replicates, as part of another trial. Plot size was approximately 0.7 ha. Sowing rates were 2,10 and $2 \mathrm{~kg} / \mathrm{ha}$ for cocksfoot, ryegrass and white clover, respectively. In addition, half of each pasture plot was oversown in March 2005 with a mixture of annual clovers: 'Bolta' balansa clover at 3 $\mathrm{kg} / \mathrm{ha}$ and 'Leura' and 'Campeda' subclovers, each at 5 $\mathrm{kg} / \mathrm{h}$. Paddocks were set-stocked with 10 Coopworth ewes +20 twin lambs/ha. Plots were grazed in common.

\section{Annual grass weed ingress}

Thirty-six seeds of vulpia and goose grass were sown approximately $5 \mathrm{~mm}$ below the soil surface on 23 
March 2005 at $5 \mathrm{~cm}$ intervals in randomly placed 30 by $30 \mathrm{~cm}$ quadrats. Two quadrats/treatment contained vulpia and two contained goose grass seeds.

The presence of vulpia and goose grass was recorded in these quadrats on 16 May, 18 August, 1 November and 22 November, about 2, 5, 7.5 and 8 months after sowing, respectively. Plants were harvested on 22 November and vulpia and goose grass tiller number, seeds/spikelet, spikelets/seedhead and seedhead numbers were recorded. Plants were then oven-dried at $80^{\circ} \mathrm{C}$ for $48 \mathrm{~h}$ and their dry weight recorded.

Additionally, pasture microsite conditions were recorded in each $5 \mathrm{~cm}$ cell of each quadrat in which a surviving plant was present, at the four measurement dates. Within the $1 \times 1 \mathrm{~cm}$ centre region of each cell, ground conditions were classed as either bare, with vegetation cover or with litter cover. If there was foliage of a neighbouring plant above the cell centre, it was categorised as having a canopy present, while if there was no foliage above the cell centre, it was categorised as having no canopy. This gave a total of 6 categories: canopy with bare ground, vegetation cover or litter cover, and no canopy with bare ground, vegetation cover or litter cover.

The same assessment was made to ascertain the frequency distribution of microsites in each pasture treatment plot- recording ground and canopy conditions at $5 \mathrm{~cm}$ intervals along a randomly-placed $1 \mathrm{~m}$ ruler.

\section{Analyses}

Data were analysed in Genstat (Version 11) using a splitsplit-plot ANOVA separately for each measurement date. Main plots (ryegrass or cocksfoot) were split for annual clovers (with and without balansa and subclover), which was split for weedy grasses (vulpia or goose grass) for each measurement date (May, August, early and late November). A chi-square test was done to compare the distribution of microsite types with the distribution of annual weedy grasses in these different microsite types.

\section{Results}

There were fewer plants of vulpia and goose grass in cocksfoot than ryegrass pastures, although differences were significant only in August $(\mathrm{P}<0.05)$. Although the number of tillers/plant $(\mathrm{P}=0.145)$, seedheads/plant $(\mathrm{P}=0.078)$, seeds/seedhead $(\mathrm{P}=0.334)$, seeds/spikelet $(\mathrm{P}=0.549)$, spikelets/seedheads $(\mathrm{P}=0.304)$ and seeds/ plant $(\mathrm{P}=0.171)$ of annual grasses were consistently less in cocksfoot than ryegrass pastures, differences did not reach statistical significance $(\mathrm{P}>0.05$, Table 1$)$.

Survival of grass weeds was reduced by oversowing annual clovers, with a significant reduction occurring on 1 November $(\mathrm{P}<0.05)$. Fecundity (seeds/seedhead) was also reduced by oversowing $(\mathrm{P}<0.05$, Table 1$)$.

On only one occasion was there an interaction, which was between pasture types and annual grass weeds. In May, vulpia survival was greater $(\mathrm{P}<0.001)$ in ryegrass

Table 1 Establishment (\%), survival (\%), growth (dry weight/plant, tillers/plant) and seed production of vulpia and goose grass in cocksfoot and ryegrass-based pastures with $(+\mathrm{Clo})$ and without $(-\mathrm{Clo})$ subterranean and balansa clovers. Means with different subscripts are significantly different $(\mathrm{P}<0.05)$.

\begin{tabular}{lcccccc}
\hline Survival and growth & Cocksfoot & Ryegrass & SED & +Clo & - Clo & SED \\
\hline Establishment (\%)16 May & 19.1 & 22.2 & 3.38 & 18.6 & 22.8 & 2.18 \\
Establishment (\%) 18 Aug & $22.1_{\mathrm{a}}$ & $35.1_{\mathrm{b}}$ & 3.54 & 29.5 & 27.6 & 3.05 \\
Survival (\%) 1 Nov & 20.0 & 19.6 & 2.90 & $15.6_{\mathrm{a}}$ & $23.9_{\mathrm{b}}$ & 3.30 \\
Survival (\%) 22 Nov & 14.6 & 16.0 & 3.75 & 11.1 & 19.4 & 3.44 \\
Dry weight (g)/plant & 0.06 & 0.06 & 0.009 & 0.04 & 0.08 & 0.019 \\
Tillers/plant & 2.5 & 3.1 & 0.30 & 3.0 & 2.6 & 0.41 \\
Seeds/seedhead & 14.8 & 23.4 & 7.52 & $12.1 \mathrm{a}$ & $26.0 \mathrm{~b}$ & 5.63 \\
Seedheads/plant & 0.7 & 1.2 & 0.17 & 0.8 & 1.1 & 0.18 \\
Seeds/plant & 13.4 & 38.8 & 14.2 & 38.2 & 14.0 & 12.55 \\
\hline
\end{tabular}

Table 2 Percentage of microsite types on 16 May, in cocksfoot and ryegrass pastures with (+Clo) and without (-Clo) subterranean and balansa clovers. Means with different subscripts are significantly different $(P<0.05)$.

\begin{tabular}{|c|c|c|c|c|c|c|c|}
\hline Canopy & Ground & Cocksfoot & Ryegrass & SED & + Clo & $-\mathrm{Clo}$ & SED \\
\hline \multirow[t]{3}{*}{ Canopy } & Bare & $13.7_{a}$ & $30.8_{b}$ & 3.34 & 23.2 & 21.3 & 2.16 \\
\hline & Litter & 25.9 & 20.4 & 4.60 & 26.2 & 20.1 & 2.67 \\
\hline & Vegetation & 40.9 & 28.0 & 5.56 & 33.2 & 35.7 & 3.79 \\
\hline \multirow[t]{3}{*}{ No canopy } & Bare & 7.9 & 10.4 & 5.05 & $6.4_{a}$ & $11.9_{b}$ & 1.53 \\
\hline & Litter & 10.4 & 9.1 & 1.80 & 9.5 & 10.0 & 1.83 \\
\hline & Vegetation & 1.2 & 1.2 & 0.86 & 1.5 & 0.9 & 1.06 \\
\hline
\end{tabular}


Table 3 Frequency distribution (\%) of vulpia and goose grass in different microsite types between establishment and seed production (expressed as a percentage of surviving plants). The distribution of microsite types (percentage of total types) is in parenthesis. Chi-squared probabilities are given for a comparison of the two distributions.

\begin{tabular}{|c|c|c|c|c|c|}
\hline Canopy & Ground & 16 May & 18 Aug & $1 \mathrm{Nov}$ & $22 \mathrm{Nov}$ \\
\hline \multirow[t]{3}{*}{ Canopy } & Bare & $13(22)$ & $70(63)$ & 89 (18) & $97(27)$ \\
\hline & Litter & $14(23)$ & 8 (9) & $3(41)$ & $0(10)$ \\
\hline & Vegetation & 6 (35) & $5(25)$ & 1 (39) & $0(62)$ \\
\hline \multirow[t]{3}{*}{ No canopy } & Bare & $47 \quad(9)$ & 15 (2) & $7 \quad$ (2) & 3 (1) \\
\hline & Litter & $19(10)$ & 2 (1) & $0 \quad(0)$ & $0 \quad(0)$ \\
\hline & Vegetation & 2 (1) & $0 \quad(0)$ & $0 \quad(0)$ & $0 \quad(0)$ \\
\hline$\chi^{2}$ Prob & & $<0.001$ & $<0.001$ & $<0.001$ & $<0.001$ \\
\hline
\end{tabular}

$(12 \%)$ than cocksfoot (7\%) pastures, while goose grass survival was similar in both pasture types (mean $=5 \%$ ).

More vulpia (26\%) than goose grass $(15 \%)$ plants established in May $(\mathrm{P}<0.001)$, although there were no differences in survival at later dates (data not shown). Dry weight was greater $(\mathrm{P}<0.05)$ for goose grass $(76$ $\mathrm{mg} /$ plant $)$ than vulpia $(42 \mathrm{mg} / \mathrm{plant}, \mathrm{P}<0.05)$. There were no other differences between vulpia and goose grass in growth or survival. On average, only $15 \%$ of annual grass seeds sown produced plants which survived until the end of November. Each surviving plant had an average of 3 tillers and 1 seedhead with 19 seeds.

All pasture types had a greater proportion of sites with than without canopy cover (Table 2). There were more microsites with bare ground and a canopy in ryegrass than cocksfoot pastures during May (Table 2, $\mathrm{P}<0.05)$, August $(75 \%$ versus $52 \%, \mathrm{P}<0.05)$ and early November $(22 \%$ versus $14 \%, \mathrm{P}<0.05)$. There was a similar trend for microsites with bare ground and no canopy, although differences were not significant (Table 2, $\mathrm{P}>0.05$ ).

Oversowing with annual clovers reduced the proportion of microsites with bare ground and no canopy (Table 2, $\mathrm{P}<0.05$ ).

By 16 May, 2 months after sowing, survival of vulpia and goose grass was greatest where the ground was bare and no canopy was present (Table 3). Thereafter, survival was greater where the ground was bare but a canopy was present. The distribution of microsites also changed, with a notable increase in sites with bare ground and canopy cover. Microsites with vegetation and canopy cover also remained high. The significant chi-square test statistic indicates that the distribution of annual grass weeds across the microsite types was not proportional to the abundance of the microsite types in the pasture $(\mathrm{P}<0.001$, Table 3$)$.

\section{Discussion}

Oversowing annual legumes reduced survival and fecundity of both weedy annual grasses. Annual legumes germinate in autumn at a similar time as the annual weedy grasses and therefore they compete for space. This was reflected in the reduction of bare ground microsites without a canopy when legumes were oversown. Lack of space and competition from these legumes would make it more difficult for the annual grass weeds to establish and survive. However, legumes would also fix a small amount of nitrogen and increase its availability, which may promote establishment and growth of the grass weeds. Some of the effects of differential nitrogen inputs in this study may have been reduced because the plots were grazed in common; nitrogen would be redistributed by urine deposition to plots without annual legumes. Results from this study concur with results from this site in subsequent years, where oversowing annual legumes reduced annual grass weed ingress (Tozer et al. 2007).

Cocksfoot was better than ryegrass in limiting the initial establishment of the two grass weeds in this dryland, drought-prone environment. There was also a trend towards lower survival and fecundity of both annual grass weeds in the cocksfoot pastures. There are several possible reasons for this. There was a higher proportion of bare ground in ryegrass than cocksfoot pastures throughout the season. This would enhance the establishment, growth and survival of annual grasses. Including endophyte can also suppress annual grass weed ingress, as was demonstrated by comparing annual grass ingress in tall fescue pastures with and without endophyte at this site. For example, barley grass comprised $10 \%$ of cover in tall fescue swards without endophyte but only 5\% in tall fescue swards with endophyte (Tozer et al. 2007). Despite the ryegrass sown here containing endophyte, the more drought tolerant cocksfoot without endophyte was still more effective than ryegrass in reducing grass weed establishment. Another possibility is that the greater establishment of annual grass weeds in ryegrass than cocksfoot swards may be due to the more clumpy nature of cocksfoot that was observed at the site, which provided greater opportunity for sheep to selectively graze annual grass weed seedlings. Generally, both annual grasses responded similarly to the perennial 
grass and oversowing treatments, suggesting that cocksfoot and oversowing annual legumes may be effective in reducing ingress of a range of winter-active annual grass weeds such as barley grass and other brome species.

Establishment of both vulpia and goose grass occurred predominantly in microsites with bare ground and no canopy. However, as the season progressed, these annual grasses were mainly present in microsites with bare ground and a canopy. This change reflected the increase in bare ground microsites with a canopy and the decline in bare ground microsites without a canopy. A possibility is that canopy cover and associated shade may also have reduced desiccation of establishing annual grass weeds and increased their survival. This is consistent with results from other grassland studies, where shelter from neighbouring plants improved establishment of some species (e.g. Ryser 1993).

This study has shown that appropriate selection of grass and legume species can reduce annual grass weed ingress in dryland pastures. In particular, oversowing with annual legumes such as subclover and balansa clover can reduce annual grass weed ingress, regardless of the perennial grass species sown. Cocksfoot may also be more effective than ryegrass in reducing annual grass weed establishment in dryland pastures prone to summer drought. Repeating this study over several years in different environments would determine how widely these conclusions can be applied.

\section{ACKNOWLEDGEMENTS}

Thanks to Lincoln University staff for managing this site and to Lincoln University for funding this research.

\section{REFERENCES}

Bourdôt, G.W. 1996. Interference between pasture plants and thistles - a review. Plant Protection Quarterly 11: 265-270.

Burton, J.; Dowling, P. Eds. 2004. Pasture management for weed control: a grazier's guide to controlling annual weeds in southern Australian improved pastures. NSW Agriculture and the Co-operative Research Centre for Australian Weed Management, Orange, New South Wales, Australia.

Dowling, P.M.; Leys, A.R.; Verbeek, B.; Millar, G.D.; Lemerle, D.; Nicol, H.I. 2004. Effect of annual pasture composition, plant density, and soil fertility and drought on vulpia (Vulpia bromoides (L.) S.F. Gray). Australian Journal of Agricultural Research 55: 1097-1107.

Lolicato, S.; Rumball, W. 1994. Past and present improvement of cocksfoot (Dactylis glomerata L.) in Australia and New Zealand. New Zealand Journal of Agricultural Research 37: 379-390.

Ryser, P. 1993. Influences of neighbouring plants on seedling establishment in limestone grassland. Journal of Vegetation Science 4: 195-102.

Tozer, K.N.; Lucas, R.H.; Edwards, G.R. 2007. Suppression of annual grass weeds by AR542 endophyte infection in dryland tall fescue pastures. New Zealand Plant Protection 60: 164-167. 